Article

\title{
Entomopathogenic Potential of Simplicillium lanosoniveum Native Strain in Suppressing Invasive Whitefly, Aleurodicus rugioperculatus Martin (Hemiptera: Aleyrodidae), Infesting Coconut
}

\author{
Maruthakasi Sujithra ${ }^{1, *}$, Hanumanthappa Veerappa Prathibha ${ }^{1}\left(\mathbb{D}\right.$, Manikappa Rajkumar ${ }^{1}$, \\ Govindharaj Guru-Pirasanna-Pandi ${ }^{2, * \mathbb{D}}$, Sengottayan Senthil-Nathan ${ }^{3, * \mathbb{D}}$ and Vinayaka Hegde ${ }^{1}$
}

check for updates

Citation: Sujithra, M.; Prathibha, H.V.; Rajkumar, M.;

Guru-Pirasanna-Pandi, G.; Senthil-Nathan, S.; Hegde, V. Entomopathogenic Potential of Simplicillium lanosoniveum Native Strain in Suppressing Invasive Whitefly, Aleurodicus rugioperculatus Martin (Hemiptera: Aleyrodidae), Infesting Coconut. J. Fungi 2021, 7, 964. https://doi.org/10.3390/ jof7110964

Academic Editor: Frank Pasmans

Received: 11 October 2021

Accepted: 10 November 2021

Published: 12 November 2021

Publisher's Note: MDPI stays neutral with regard to jurisdictional claims in published maps and institutional affiliations.

Copyright: (C) 2021 by the authors Licensee MDPI, Basel, Switzerland. This article is an open access article distributed under the terms and conditions of the Creative Commons Attribution (CC BY) license (https:/ / creativecommons.org/licenses/by/ $4.0 /)$.
1 Division of Crop Protection, Central Plantation Crop Research Institute, ICAR, Kasaragod 671124, India; prathibhacpcri@gmail.com (H.V.P.); rajkumarcpcri@gmail.com (M.R.); hegdev64@gmail.com (V.H.)

2 Division of Crop Protection, National Rice Research Institute, ICAR, Cuttack 753006, India

3 Division of Biopesticides and Environmental Toxicology, Sri Paramakalyani Centre for Excellence in Environmental Sciences, Manonmaniam Sundaranar University, Tirunelveli 627412, India

* Correspondence: amitysuji@gmail.com (M.S.); guru.g@icar.gov.in (G.G.-P.-P.); senthil@msuniv.ac.in (S.S.-N.); Tel.: +91-(04994)-232894 (M.S.); Fax: +91-(04994)-232322 (M.S.)

\begin{abstract}
In 2016, infestation of an exotic polyphagous pest, the rugose spiraling whitefly (RSW), Aleurodicus rugioperculatus Martin (Hemiptera: Aleyrodidae), was documented on coconut for the first time in India. Instantaneously, RSW has garnered wide attention owing to its damage severity and rapid spread across the coconut-growing regions of the country. Hence, an attempt was made to devise a sustainable integrated pest management (IPM) module using biological control agents as a mainstay component. The present study documented the identification and characterization of a potential entomopathogenic fungal isolate for the management of RSW. An entomopathogenic fungus isolated from nymphal cadavers of RSW was identified as Simplicillium lanosoniveum based on morphological and phylogenetic analyses. A gradient of five conidial concentrations $\left(1 \times 10^{4}\right.$, $1 \times 10^{5}, 1 \times 10^{6}, 1 \times 10^{7}$ and $1 \times 10^{8}$ conidia/mL) of the $S$. lanosoniveum were tested against eggs, first instars, second to third instars and pupae of RSW. Results revealed that S. lanosoniveum is highly virulent to all developmental stages of RSW by causing mortality rates of $95.20 \%, 87.33 \%, 85.38 \%$ and $72.85 \%$, in eggs, initial, middle and later instar nymphs of RSW, respectively, at the highest tested concentration $\left(1 \times 10^{8}\right.$ conidia/mL) at seven days after exposure. The $\mathrm{LC}_{50}$ and $\mathrm{LT}_{50}$ values of S. lanosoniveum were $4.72 \times 10^{4}, 4.94 \times 10^{4}, 5.11 \times 10^{5}, 5.92 \times 10^{5}$ conidia/mL and 4.27, 4.86, 4.56, 5.89 days against eggs, initial, middle and later instar nymphs of RSW, respectively. Further, preliminary field trials with $S$. lanosoniveum strain at $1 \times 10^{8}$ conidia $/ \mathrm{mL}$ exhibited a significant reduction in the egg and nymphal population by $57.8 \%$ and $56.3 \%$, respectively. This report thus demonstrated that the newly isolated S. lanosoniveum is an effective pathogen at suppressing all the developmental stages of RSW. This is the first record of S. lanosoniveum infecting RSW, and it has a great potential to be developed as a mycoinsecticide.
\end{abstract}

Keywords: plantation; environmental safety; whitefly; invasive pest; mycoinsecticide; entomopathogenic fungi

\section{Introduction}

Rugose Spiraling Whitefly (RSW), Aleurodicus rugioperculatus Martin (Hemiptera: Aleyrodidae) is an introduced pest, whose infestation on coconut was reported for the first time from Pollachi, Tamil Nadu $\left(10.6609^{\circ} \mathrm{N}, 77.0048^{\circ} \mathrm{E}\right)$ and Palakkad, Kerala $\left(10.7867^{\circ} \mathrm{N}\right.$, $76.6548^{\circ}$ E) state in India [1]. RSW infestation on coconut was first described from Belize [2], and Central America is believed to be the centre of origin for the pest. RSW is a highly polyphagaous pest with more than 118 hosts belonging to 43 diverse plant 
families. Among the hosts, palms constitute $22 \%$, followed by Bursera simaruba (16\%), Calophyllum spp., (10\%), avocado (9\%), black olive (4\%), and mango varieties (3\%) [3]. RSW has already been identified as a serious threat to the cultivation of coconut palms and other Arecaceae species in Florida [4,5]. Initially, 17 plant species (belonging to 11 families) were recorded as preferred hosts for RSW after the pest reached South Kerala [6]. Subsequently, the incidence of RSW was reported in the states of Kerala, Karnataka, Andhra Pradesh, Assam, Goa, West Bengal, Maharashtra and Gujarat on several crops such as coconut, banana, sapota, corn, oil palm, mango, cashew and many other ornamental plants $[7,8]$. The availability of a wide range of host plants, combined with congenial climatic conditions, favored their successful establishment in the areas of invasion. Both the nymphs and adults of RSW directly suck the phloem sap of the leaf and secrete honey dew which encourages the growth of sooty mould on the leaf surface that eventually reduces the photosynthesis in the affected palms. Currently, RSW has become a regular pest of coconut, warranting effective integrated pest management (IPM) strategies.

Among the various biocontrol agents, entomopathogenic fungi (EPF) have been found to be successfully developed as mycopesticides in managing piercing-sucking groups of insects including whiteflies. Whiteflies are known to be infected by more than 20 species of entomopathogenic fungi, of which some of the widely studied fungi are Beauveria bassiana (Vuillemin), Akanthomyces lecanii (Zimm.) and Cordyceps fumosorosea (Wize) [9-12]. EPFs are considered as potent alternatives for whitefly management because of their unique ability to invade the host insects directly by penetrating through the integument without the concern of resistance development [13].

Severe infestation of RSW in palm oil resulted in a reduction of $20-25 \%$ bunch yield at Andhra Pradesh [14]. Likewise, RSW has become a serious predicament for coconut growers, hence efforts were made to identify the indigenous potential biological control associated with the invasive pest. The fungal strain was identified and characterized based on morphological descriptions coupled with molecular analysis. To the best of our knowledge, this is the first report of the occurrence of entomopathogenic fungi, S. lanosoniveum (Cordycipitaceae: Hypocreales) on RSW. Furthermore, the efficacy of the indigenous fungal strain was investigated under laboratory and field bioassays in order to develop a biopesticide for the management of this emerging pest.

\section{Materials and Methods}

\subsection{Insect Cultures}

RSW adults were collected from infested coconut gardens of the research farm belonging to ICAR - Central Plantation Crops Research Institute (ICAR-CPCRI), Kasaragod, Kerala, India $\left(12^{\circ} 30^{\prime} \mathrm{N}\right.$ latitude, $75^{\circ} 00^{\prime} \mathrm{E}$ longitude and $\left.10.7 \mathrm{~m}\right)$. RSW culture was reared on coconut seedlings raised in pots placed in the greenhouse with natural photoperiodic conditions. Different developmental stages of RSW such as eggs, first instar, second instar, third instar and fourth instar nymphs (pupae) were collected from the reared culture and were used for bioassay studies.

\subsection{Fungal Isolation}

RSW nymphal cadavers $(n=4)$ fully covered with fungal mycelia under natural growth conditions were collected from a coconut garden at ICAR-CPCRI, Kasaragod $\left(12^{\circ} 30^{\prime} \mathrm{N}\right.$ latitude, $75^{\circ} 00^{\prime} \mathrm{E}$ longitude and $\left.10.7 \mathrm{~m}\right)$. Sterile needles were used to isolate mycelia or conidia from the cuticles of nymphal cadavers transferred to a Petri plate containing Potato Dextrose Agar (PDA) medium and cultured at $26 \pm 1{ }^{\circ} \mathrm{C}$ and $60 \% \mathrm{RH}$ for 7-10 days in a biochemical incubator (BOD). In order to isolate the pure culture, the hyphal tip from a small fungal colony was transferred to PDA slants and incubated at $26 \pm 1{ }^{\circ} \mathrm{C}$ and $60 \% \mathrm{RH}$. The morpho-taxonomic characteristics of the fungus were identified based on conidia-forming mycelia and conidial structure $[15,16]$. 


\subsection{Identification of the Fungus}

\subsubsection{Morphological Identification}

Morphological identification of the fungal isolate was recorded on PDA medium incubated at $26 \pm 1{ }^{\circ} \mathrm{C}$ and $60 \% \mathrm{RH}$ for seven to ten days. The micro-morphological features were recorded under a compound microscope (Nikon Eclipse 80i) attached with a digital camera. The identification of the fungus was further confirmed with the help of Fungal Identification Services, Agharkar Research Institute (ARI), Pune, Maharashtra, India.

\subsubsection{Genetic Identification}

Total genomic DNA was extracted from five-day old single spore cultures of fungus grown in $100 \mathrm{~mL}$ Potato Dextrose broth. After vacuum filtration, the mycelia were washed with sterilized distilled water and powdered using liquid nitrogen with the help of a mortar and pestle. The DNA was extracted from powdered preparations using DNeasy Plant Mini Kit (Qiagen, Valencia, CA, USA) following the standard manufacturer's instructions. The fungal ITS region was amplified using the primers: ITS4 (5'-TCCTCCGCTTATTGATATGC$\left.3^{\prime}\right)$ and ITS6 (5'-GGAAGTAAAAGTCGTAACAAGG-3') [17]. Two more nuclear genes viz., elongation factor-1 alpha (TEF1- $\alpha$ ) and RNA polymerase II largest subunit 1 (RPB1) of the ribosomal RNA gene were used in addition to confirm the identification the species level. The DNA was amplified using specific primers of the TEF1- $\alpha$ (983F 5' GCYCCYGGHCAYCGTGAYTTYAT $3^{\prime}$ 2218R 5' ATGACACCRACRGCRACRGTYTG and RPB1 (CRPB1 $5^{\prime}$ CCWGGYTTYATCAAGAARGT $3^{\prime}$ and CRPB1 A $5^{\prime}$ CAYCCWGGYTTYATCAAGAA $3^{\prime}$ RPB1Cr $5^{\prime}$ CCNGCDATNTCRTTRTCCATRTA $3^{\prime}$ [18]. The resultant PCR products were excised and purified using a Qiagen Gel Extraction Kit (Qiagen India) following the standard protocol and were sequenced at Agrigenome, Cochin, India. The generated sequences were submitted to NCBI GenBank (Accession numbers: ITS = MK463992, TEF1- $\alpha=$ MW893683 and RPB1 = MW836952) and used for multi gene phylogenetic analysis. The sequences were used as query to perform BLAST search (http:/ /blast.ncbi.nlm.nih.gov/ (accessed on 8 April 2021), and the sequence similarity studies were performed using ClustalX (1.81). The phylogenetic tree of $S$. lanosoniveum was constructed following maximum likelihood (ML) method using MEGA X software [19].

\subsection{Virulence Bioassays}

\subsubsection{Conidial Preparation}

The fungal culture was inoculated in Potato Dextrose Broth (PDB) and incubated at $26 \pm 1{ }^{\circ} \mathrm{C}$ and $60 \% \mathrm{RH}$ on a shaker for 14 days. The mycelia mat along with conidia was thoroughly mixed in a mixer grinder, and the suspension was filtered through three layers of muslin cloth, in order to get a hyphal-free conidial suspension. Conidial suspensions were prepared in sterile distilled water containing $0.01 \%$ Tween 80 and the concentration of the suspension was adjusted to different conidial concentrations using Neubauer's improved haemocytometer under a Nikon eclipse 80i compound microscope. Five different spore concentrations ranging from $1 \times 10^{4}$ to $1 \times 10^{8}$ conidial concentration $/ \mathrm{mL}$ were tested against different developmental stages of RSW.

\subsubsection{Experimental Design}

Coconut leaf bits containing 35-40 different developmental stages of RSW were collected from the greenhouse culture. Thirty leaf bits $(10 \mathrm{~cm}$ each) were gently dipped in freshly prepared respective conidial suspensions for $20 \mathrm{~s}$ and placed separately on a Petri plate $(14 \times 2.5 \mathrm{~cm})$ over sterilized wet tissue paper. Sterile distilled water containing $0.01 \%$ Tween 80 alone was used as the control. The experiment had five replications for each concentration, and the whole bioassay was repeated twice. Prior to conidial spray, the number of various developmental stages of RSW on each coconut leaf bit was counted to maintain a uniform population across the treatments. The mortality data were recorded by counting dead cadavers and developmental stages with fungal infection at $24 \mathrm{~h}$ intervals up to seven days, and the data was subjected to Abbott's formula [20] for calculating corrected 
mortality. For time mortality studies, the higher concentration at $1 \times 10^{8}$ spores $/ \mathrm{mL}$ were used to determine $\mathrm{LT}_{50}$ of $S$. lanosoniveum against RSW developmental stages.

\subsection{Field Virulence of S. lanosoniveum}

Two field trials using S. lanosoniveum carried out during November 2019 and January 2020, respectively, in the RSW infested coconut gardens of ICAR-CPCRI, Kasaragod, Kerala (average temperature $22-33{ }^{\circ} \mathrm{C}, 60-73 \% \mathrm{RH}$ during December 2019 and average temperature $20.6-32.4{ }^{\circ} \mathrm{C}, 59-71 \% \mathrm{RH}$ during January 2020 , respectively). The conidial suspension of the fungal culture $\left(1 \times 10^{8}\right.$ conidia $\left./ \mathrm{mL}\right)$ was prepared in sterile aqueous solution containing $0.01 \%$ Tween 80 . The spore suspension of $500 \mathrm{~mL}$ was sprayed thoroughly on the dwarf cultivars of each coconut tree (variety; Chowghat Orange Dwarf (COD), $n=20$ ) which were naturally infested with different developmental stages of RSW through handheld sprayer. Prior to fungal spray, the numbers of developmental stages of RSW per leaflet (5 leaflets per palm) were counted under a Nikon Stereozoom microscope (SMZ $800 \mathrm{~N}$ ). Twenty dwarf palms sprayed with sterile aqueous solution containing $0.01 \%$ Tween 80 were maintained as control. Mortality data ware recorded from the treated and control plants after 14 days of spray. The experiment was replicated thrice and field bioassays were conducted twice at different time intervals. Developmental stages with S. lanosoniveum fungal infection recorded using a Nikon Stereozoom microscope (SMZ $800 \mathrm{~N}$ ) and the percent mortality was calculated.

\subsection{Statistical Analysis}

Conidial concentration, time and their interactive effects on mortality per cent data were analyzed using PROC GLM (SAS version 9.3, SAS institute, 2011). Mortality data of different developmental stages of A. rugioperculatus were corrected using Abbott's formula [20]. The treatment difference was evaluated using least significant difference (LSD) at $p<0.05$. The dose and time dependent mortality studies to kill $50 \%$ of the population ( $\mathrm{LC}_{50}$ and $\mathrm{LT}_{50}$ ) were calculated by probit analysis [21] using R software based on binomial GLM function [22,23]. Field efficacy data were assessed by Student's $t$-test with a significance of difference at $p<0.01$ [24].

\section{Results}

\subsection{Fungal Identification}

\subsubsection{Morphological Identification}

Based on the morphological characters, the fungus isolated from the field collected nymphal cadavers of $A$. rugioperculatus was identified as Simplicillium lanosoniveum (Cordycipitaceae: Hypocreales). The fungal colonies were characterized on PDA medium as white, velvety with radial cracks and primrose yellow on the reverse side (Figure 1). Conidia was $(2-4 \times 1-2 \mu \mathrm{m})$, oval ellipsoidal, hyaline, smooth walled, adhering in globose to ellipsoidal head at the apex of phialides (Figure 1).

\subsubsection{Genetic Identification}

The sequences of Simplicillium isolate generated in the present study have been deposited in GenBank with accession numbers: ITS $=$ MK463992, TEF1- $\alpha=$ MW836952 and RPB1 $=$ MW893683. BLAST analysis of generated sequences exhibited $99 \%$ sequence similarity with Simplicillium lanosoniveum (DQ522406 and DQ522357). A phylogenetic tree of Simplicillium at species level was generated using maximum-likelihood (ML) analysis based on a combined data set of ITS, TEF1- $\alpha$ and RPB1. Multigene phylogenetic analysis showed that Simplicillium isolate (MK463992, MW836952 and MW893683) of the present study have a close phylogenetic affinity to Simplicillium lanosoniveum with strong bootstrap support (98-100\%, Figure 2). 

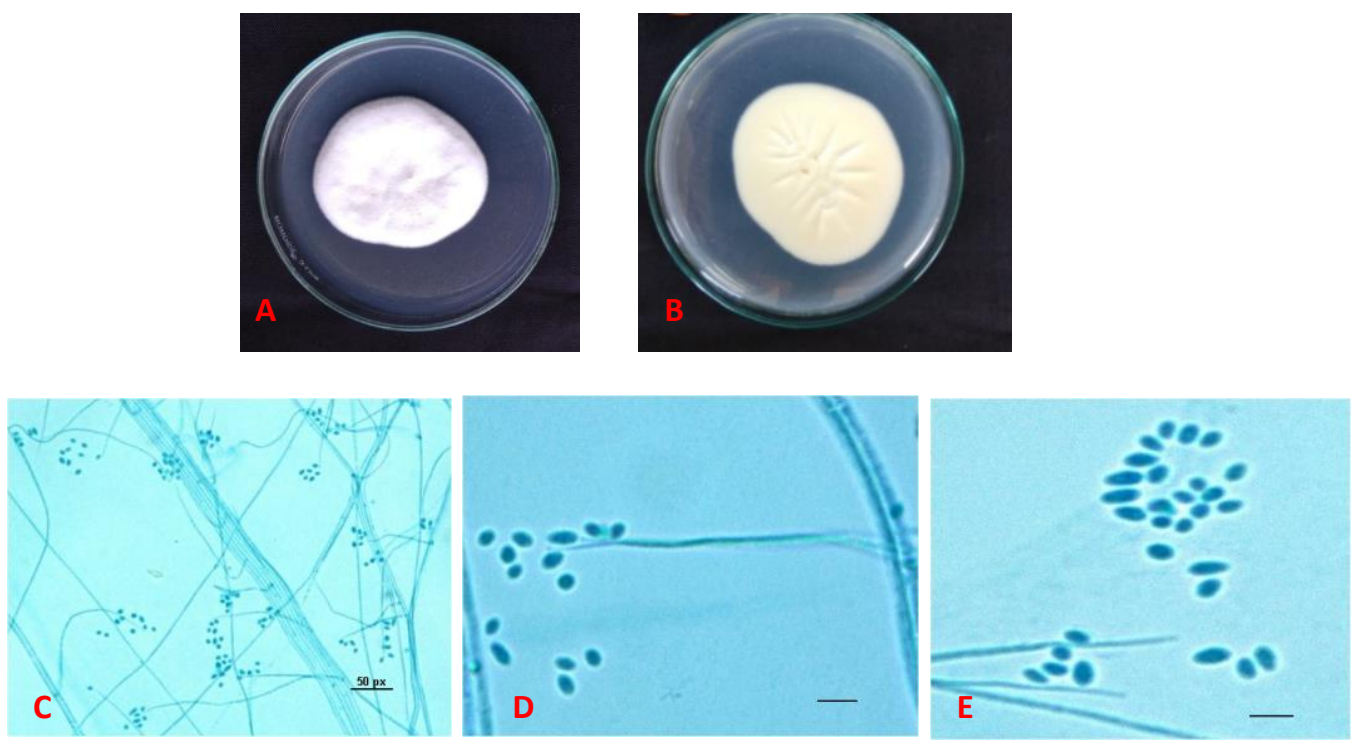

Figure 1. Morphological characters of Simplicillium lanosoniveum. (A,B) Simplicillium lanosoniveum cultured on PDA medium at $26^{\circ} \mathrm{C}$ for 10 days (A) the front side (B) the reverse side (C,D) Conidiophores with conidiogenous cells (E) Conidia—cylindrical, oval-ellipsoidal $(2-4 \times 1-2.0 \mu \mathrm{m})$; scale bar (D,E); $50 \mu \mathrm{m}$.

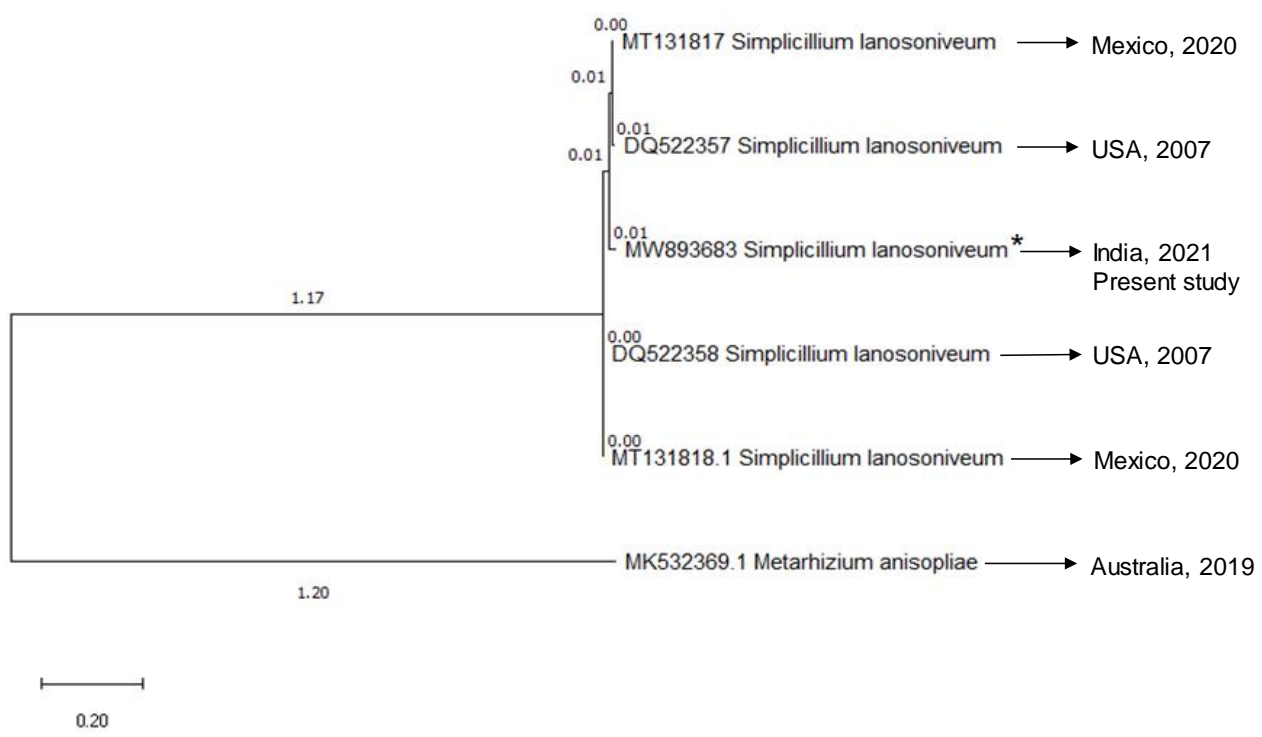

Figure 2. Phylogenetic tree based on maximum-likelihood analysis of combined ITS, b-tubulin and EF-1a sequences data. The sequence MW893683 $\left(^{*}\right)$ is the sequence generated in the present study and it branched with the retrieved sequences of S. lanosoniveum. Metarhizium anisopliae (MK532369.1) represented the outgroup.

\subsection{Virulence Bioassay}

The pathogenicity of S. lanosoniveum was evaluated against different developmental stages of RSW. The fungal bioassay treatment resulted in the highest pathogenicity to the eggs, initial (first), middle (second-third) and later (fourth) instar nymphs of RSW with corrected mortality rates of $95.20 \%, 87.33 \%, 85.38 \%$ and $72.85 \%$, respectively following the seventh day after treatment (DAT) at $1 \times 10^{8}$ conidial concentrations $/ \mathrm{mL}$ (Figure 3). 


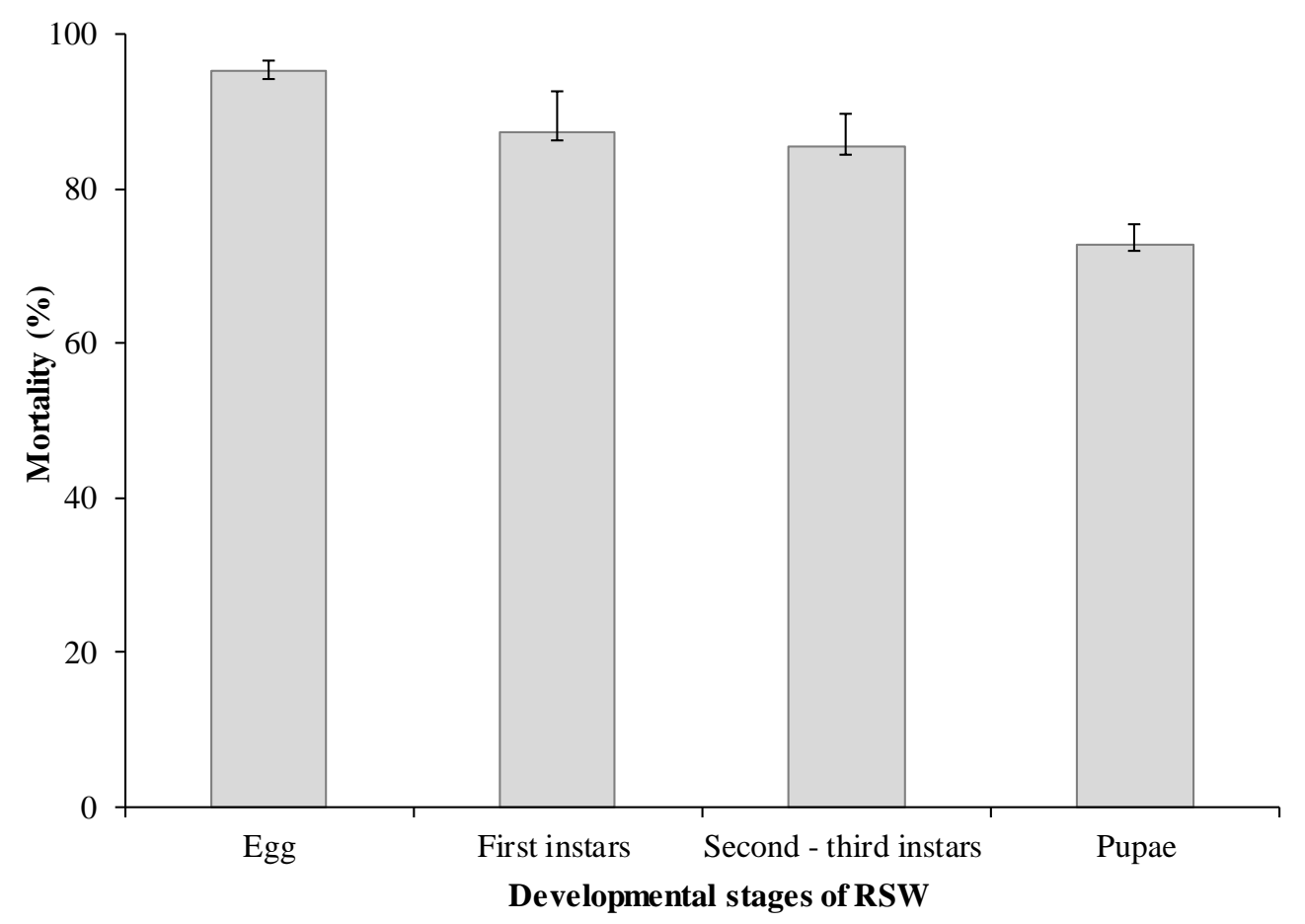

Figure 3. Pathogenecity of $S$. lanosoniveum tested at $1 \times 10^{8}$ conidia/mL against different developmental stages of RSW. Data are mean \pm SEM of three tests.

Different conidial concentration ranging from $1 \times 10^{4}$ to $1 \times 10^{8}$ conidia/mL treated against different developmental stages of RSW for evaluating its virulence are illustrated in Figure 4. The highest egg mortality of $95.20 \%$ was observed at higher conidial concentrations tested, $\left(1 \times 10^{8}\right.$ conidia $\left./ \mathrm{mL}\right)$ while low conidial concentration $\left(1 \times 10^{4}\right.$ coni$\mathrm{dia} / \mathrm{mL})$ exhibited mortality of $41.25 \%$ at $7 \mathrm{DAT}(F=40.46$; $\mathrm{df}=4,16 ; p<0.0001)$ (Figure 4$)$. Expectedly, egg mortality was found to increase with the increase in spore concentrations and exposure time $(F=52.61 ; \mathrm{df}=3,12 ; p<0.0001)$. Likewise, first instars experienced highest mortality $(87.33 \%)$ at conidial concentrations of $10^{8}$ conidia $/ \mathrm{mL}(F=8.18$; $\mathrm{df}=4,16 ; p<0.0001)$ whereas lowest per cent mortality $(39.64 \%)$ was observed at a dose of $10^{4}$ conidia/mL on 7 DAT (Figure 4). As observed in eggs, mortality in first instar nymphs increased significantly with increase in conidial concentration in each dose tested and with an increase in treatment period $(F=2.46$; $\mathrm{df}=12 ; p<0.01)$. Similarly, on seven DAT, the highest mortality of $85.38 \%$ was observed in second to third instar nymphs treated with conidial concentrations of $10^{8}$ conidia $/ \mathrm{mL}$ and the lowest concentration of $10^{4}$ conidia $/ \mathrm{mL}$ recorded lowest mortality of $35.38 \%(F=17.90 ; \mathrm{df}=4,16 ; p<0.0001)$ (Figure 4$)$.

In case of pupae, highest mortality of $72.85 \%$ was documented with the dose of $10^{8}$ conidia $/ \mathrm{mL}$, whereas the lowest mortality of $24.76 \%$ was observed at the dose of $10^{4}$ conidia/mL on 7 DAT $(F=14.96 ; \mathrm{df}=4,16 ; p<0.0001)$. The mean mortality in pupae ranged from $1.25 \%$ to $4.33 \%$ on 4 DAT when treated with conidial concentration of $10^{4}$ conidia $/ \mathrm{mL}(F=18.65 ; \mathrm{df}=3,12 ; p<0.0001)$ and $10^{8}$ conidia $/ \mathrm{mL}(F=40.80 ; \mathrm{df}=3,12$; $p<0.0001$ ), respectively (Figure 4). A similar trend of increase in mortality with increase in conidial concentration of each dose tested and exposure time was also observed in pupae $(F=7.34 ; \mathrm{df}=12 ; p<0.0001)$. Overall, the mortality rate at various developmental stages of RSW has significantly increased with an increase in the concentration of fungal conidia and the duration of the time following the exposure to the fungal treatments. In general, significant differences in the entomopathogenic pathogenicity of $S$. lanosoniveum against RSW were observed between conidial concentration $(F=215.29, \mathrm{df}=4 ; p<0.0001)$, time interval $(F=803.91, \mathrm{df}=3, p<0.0001)$ and stages of host insect $(F=145.64, \mathrm{df}=3 ; p<0.0001)$. Significant interactions were observed between treatment*stage of host insect $(F=12.98$, $\mathrm{df}=12, p<0.0001)$, treatment time $(F=6.55, \mathrm{df}=12, p<0.0001)$, time* ${ }^{*}$ stage of host insect 
$(F=8.20, \mathrm{df}=9, p<0.0001)$ and treatment ${ }^{*}$ stage of host insect ${ }^{*}$ time $(F=1.74, \mathrm{df}=36$, $p<0.0001)$.
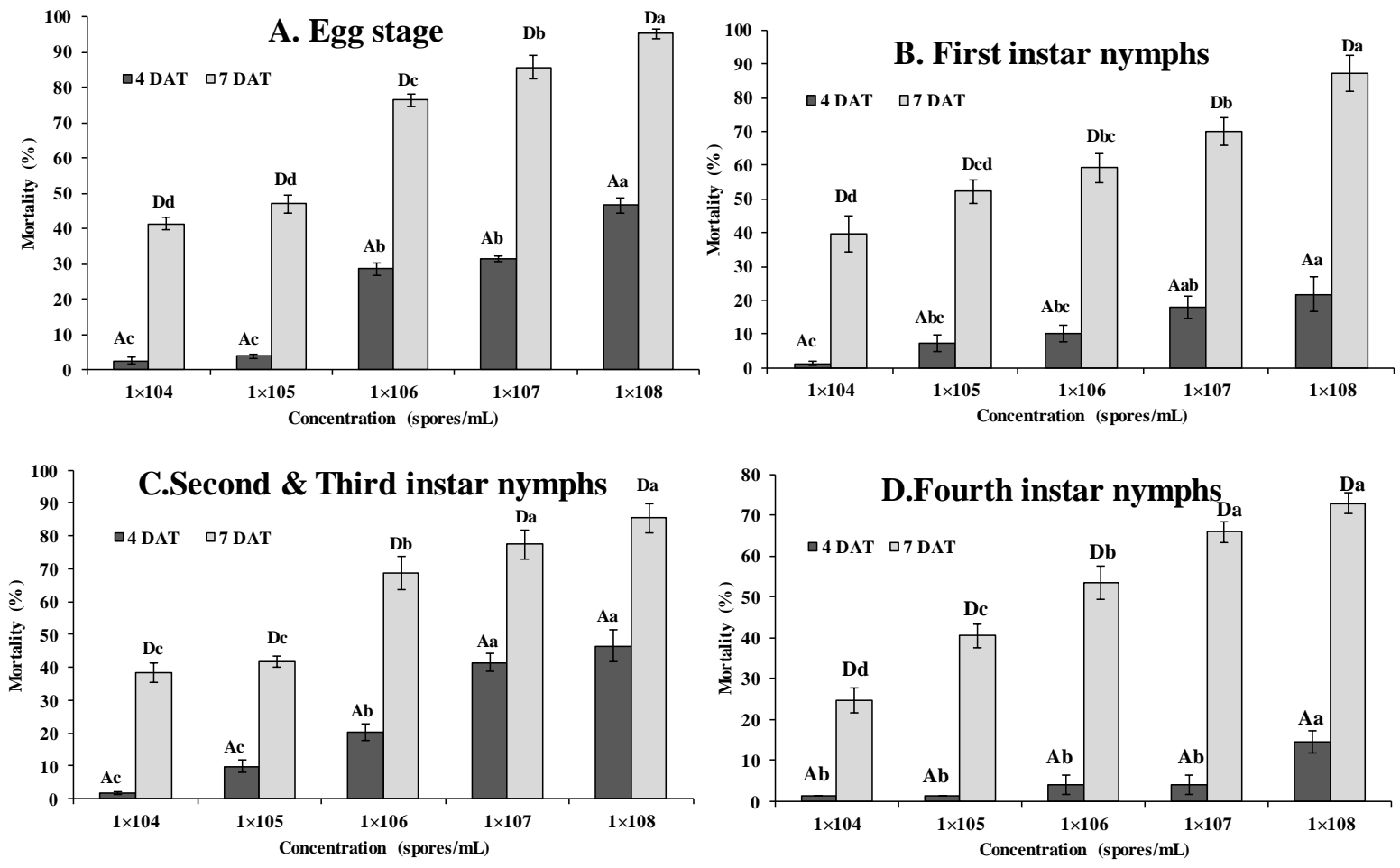

Figure 4. Mortality (\% \pm SE) of eggs (A), first instar nymphs (B), second and third instar nymphs (C), pupae (D) of A. rugioperculatus treated with fungus, Simplicillium lanosoniveum. Bars with different uppercase letters on the top of error bars indicate significant differences among the different days after treatment and with different lowercase letters indicate significant differences for different treatments i.e., concentration of fungus, Simplicillium lanosoniveum. $(p<0.05$, Tukey's test).

\subsection{Determination of the Lethal Concentration $\left(L C_{50}\right)$ and Lethal Time $\left(L T_{50}\right)$}

Significant differences in the $\mathrm{LC}_{50}$ and $\mathrm{LT}_{50}$ values of $S$. lanosoniveum against different life stages of $A$. rugioperculatus were documented based on the dose-and time mortality response studies (Table 1 ). The median lethal concentration $\left(\mathrm{LC}_{50}\right)$ values of S. lanosoniveum against eggs, first instars, second to third instarsand pupae of RSW were $4.72 \times 10^{4}, 4.94 \times 10^{4}, 5.11 \times 10^{5}, 5.92 \times 10^{5}$ conidia/mL respectively. The $\mathrm{LT}_{50}$ values of S. lanosoniveum at the highest concentration $\left(1 \times 10^{8}\right.$ spores $\left./ \mathrm{mL}\right)$ on the corresponding developmental stages were $4.27,4.86,4.56,5.89$ days, respectively (Table 2 ).

Table 1. Lethal concentration value of S. lanosoniveum against different developmental stages of RSW.

\begin{tabular}{|c|c|c|c|c|c|c|c|c|c|}
\hline \multirow{2}{*}{$\begin{array}{l}\text { Developmental } \\
\text { Stages of RSW }\end{array}$} & \multirow{2}{*}{$\mathbf{n}^{+}$} & \multirow{2}{*}{$X^{2}(\mathrm{DF}) \ddagger$} & \multirow{2}{*}{ Slope } & \multirow{2}{*}{$\mathrm{LC}_{50} *$} & \multicolumn{2}{|c|}{ LC $_{50}$ Confidence Interval } & \multirow{2}{*}{$\mathrm{LC}_{90}$} & \multicolumn{2}{|c|}{ LC $_{90}$ Confidence Interval } \\
\hline & & & & & Lower & Upper & & Lower & Upper \\
\hline Egg & 958 & $11.20(3)$ & $6.14 \pm 0.49$ & $4.723 \times 10^{4 \mathrm{a}}$ & $3.799 \times 10^{3}$ & $4.313 \times 10^{5}$ & $7.706 \times 10^{7 \mathrm{a}}$ & $6.864 \times 10^{6}$ & $9.560 \times 10^{9}$ \\
\hline First instar & 387 & $03.55(3)$ & $4.56 \pm 0.69$ & $4.946 \times 10^{4 a b}$ & $4.270 \times 10^{4}$ & $5.434 \times 10^{5}$ & $10.122 \times 10^{7 a}$ & $8.345 \times 10^{6}$ & $15.99 \times 10^{9}$ \\
\hline Second-third instar & 247 & $09.89(3)$ & $5.03 \pm 0.55$ & $5.109 \times 10^{5 \mathrm{ab}}$ & $4.653 \times 10^{4}$ & $6.350 \times 10^{6}$ & $9.536 \times 10^{8 \mathrm{a}}$ & $7.571 \times 10^{6}$ & $15.221 \times 10^{10}$ \\
\hline Fourth instar/pupae & 204 & $00.26(3)$ & $4.07 \pm 0.76$ & $5.920 \times 10^{5 b}$ & $5.232 \times 10^{5}$ & $6.700 \times 10^{6}$ & $11.383 \times 10^{8 \mathrm{a}}$ & $9.099 \times 10^{7}$ & $19.937 \times 10^{10}$ \\
\hline
\end{tabular}

${ }^{\dagger}$ - Number of insect used for bioassay study; ${ }^{\ddagger}$-Degree of freedom. * ${ }^{*}-\mathrm{LC}_{50}$ of one treatment is significantly different if the both lower and upper fiducial limit does not include $\mathrm{LC}_{50}$ value of other treatments; the $\mathrm{LC}_{50}$ values are expressed as concentration of conidia $\mathrm{mL}^{-1}$. Different letters in the superscript denotes significant difference between treatments. 
Table 2. Time-dose toxicity of S. lanosoniveum against different developmental stages of $A$. rugioperculatus at the concentration of $1 \times 10^{8}$ conidia per $\mathrm{mL}$.

\begin{tabular}{|c|c|c|c|c|c|c|}
\hline \multirow{2}{*}{$\begin{array}{l}\text { Developmental } \\
\text { Stages of RSW }\end{array}$} & \multirow{2}{*}{$\mathbf{n}^{+}$} & \multirow{2}{*}{$\mathrm{X}^{2}(\mathrm{DF}) \ddagger$} & \multirow{2}{*}{ Slope } & \multirow{2}{*}{$\mathbf{L T}_{50} *$} & \multicolumn{2}{|c|}{$\mathbf{L T}_{50}$ Confidence Interval } \\
\hline & & & & & Lower & Upper \\
\hline Egg & 165 & $1.523(4)$ & $5.54 \pm 0.38$ & $4.27^{\mathrm{a}}$ & 4.09 & 4.45 \\
\hline First instar & 43 & $0.565(4)$ & $7.67 \pm 0.91$ & $4.86^{\mathrm{b}}$ & 4.57 & 5.16 \\
\hline Second-third instar & 63 & $2.406(4)$ & $5.16 \pm 0.59$ & $4.56^{\mathrm{ab}}$ & 4.23 & 4.88 \\
\hline Fourth instar/pupae & 35 & $2.680(4)$ & $10.4 \pm 1.29$ & $5.89^{c}$ & 5.59 & 6.20 \\
\hline
\end{tabular}

${ }^{\dagger}$-Number of insect used for bioassay study; ${ }^{\ddagger}$-Degree of freedom. *- $\mathrm{LT}_{50}$ of one treatment is significantly different if the both lower and upper fiducial limit does not include $\mathrm{LT}_{50}$ value of other treatments; the $\mathrm{LT}_{50}$ values are expressed as time taken in terms of days (d) to kill $50 \%$ population. Different letters in the superscript denotes significant difference between treatments.

\subsection{Field Virulence of Entomopathogenic Fungi}

Fourteen days after the spray of $S$. lanosoniveum, the mortality of eggs and nymphal stages of RSW was calculated. As shown in Figure 5, the population of eggs $(t=4.56$; $p<0.01)$ and nymphs $(t=8.19 ; p<0.01)$ of $A$. rugioperculatus were reduced by $57.8 \%$ and $56.3 \%$, respectively at 14 DAT. Thus, the native fungi isolated and reported herein showed positive virulence by infecting RSW stages under open field conditions (Figure 5).

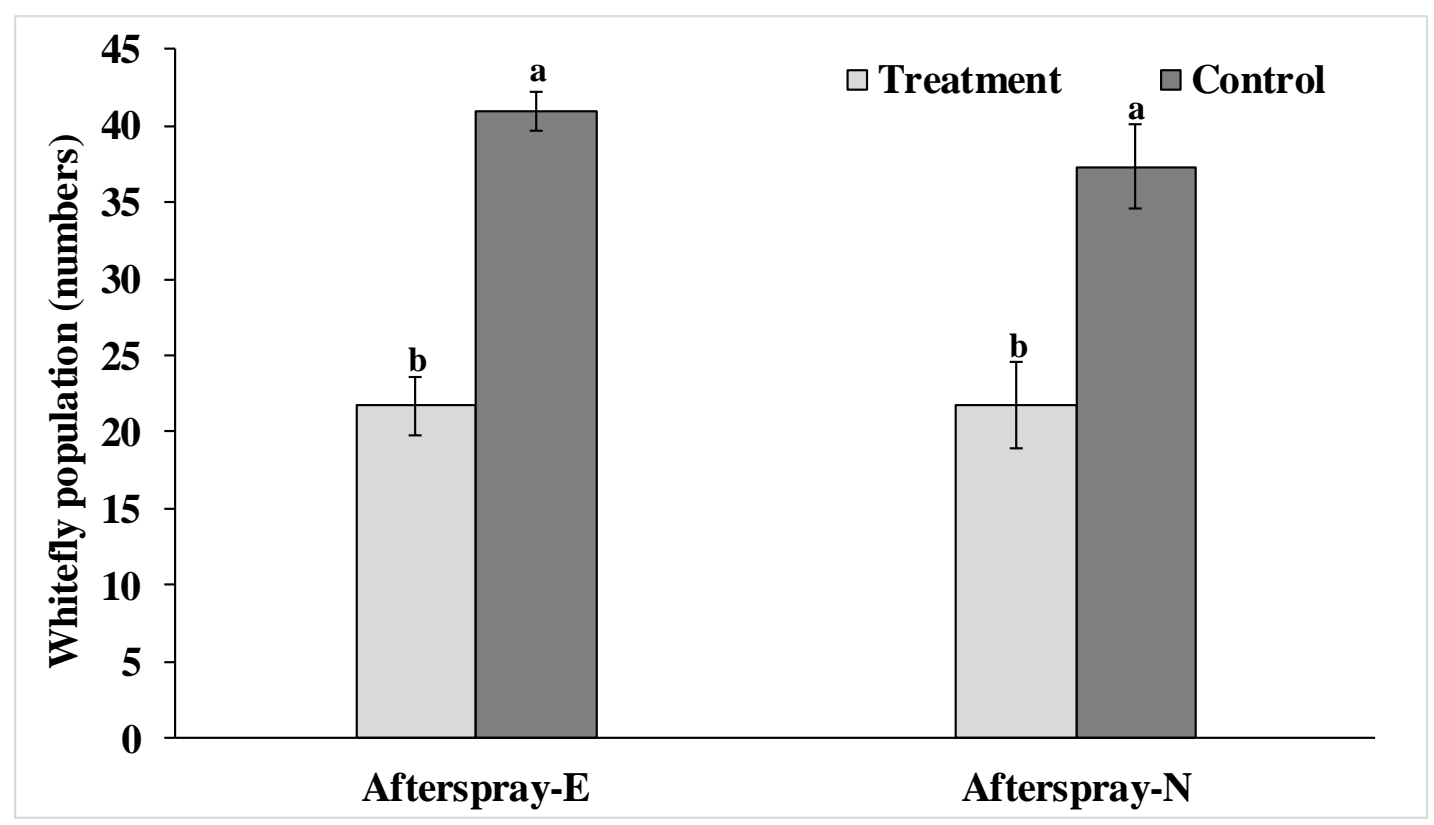

Figure 5. Field evaluation of S. lanosoniveum on the egg and nymphal population of RSW at 14 days after treatment (DAT). The different letters in Afterspray-E and Afterspray-N indicate differences between treatments. E-egg populations; N-nymphal populations.

\section{Discussion}

The first incidence of the RSW was identified in India during the year 2016 following which it has spread widely and caused serious damages in larger areas of crop cultivation, particularly in coconut [6-8]. The adoption of management strategies using chemical pesticides is uneconomical and it also causes severe adverse effects on naturally existing biocontrol agents including Encarsia guadeloupae Viggiani (Hymenoptera: Aphelinidae) [7,8]. The conservation of natural enemy complexes and avoidance of insecticide spray are the major pest management strategies provided to the farmer's against this invasive pest to avoid the ill effects of pesticide usage. In this context, utilization of entomopathogenic fungi as a means for biological control of RSW infestations is of significant importance [3-6]. 
However, exploration and identification of novel and virulent EPF strains adapted to particular localities is necessary for the development of effective mycoinsecticides. Efficacy of entomopathogenic fungi for managing the sucking insect pest population in the field conditions is well recognized [25] owing to their unique mode of action of penetrating the insect cuticle $[26,27]$. Among the EPFs, Akanthomyces species are widely utilized as commercial biological pesticides against whiteflies, thrips and aphids [28]. Fungicolous and entomopathogenic species of Akanthomyces were later placed in the genera Simplicillium and Lecanicillium based on systematic studies [16]. Although species of Simplicillium occurs in a broad range of ecological niches [16,29-32] but only few studies have reported the pathogenicity of Simplicillium sp. against insects [33-40]. In the present study, we report the identification of a novel isolate of entomopathogenic fungus, $S$. lanosoniveum isolated from RSW in the invaded region. Bioassay studies have revealed the potency of the isolate S. lanosoniveum, as it was found to be virulent against all the developmental stages of RSW. The ecological and economical value of Simplicillium sp. for its biocontrol and bioactive features were highlighted by many researchers [41-43]. S. lanosoniveum is a known phytopathogen, causing brown spots and lesions on flowers [44] or as a mycoparasite on soybean rust [45,46]. This species is also reported as a pathogen of aphids [33] and as an anti-Trichomonas vaginalis agent [47]. Other species of Simplicillium such as S. chinense acts as a biological control agent against plant parasitic nematodes $[39,48]$. S. lamellicola is known to suppress plant bacterial diseases and grey mould of tomato and ginseng [31,49]. Bioactive compounds with anti-fungal and anti-bacterial profiles and pharmaceutical exopolysaccharides were isolated from S. lanosoniveum [50-53]. Linear and cyclic peptides with anti-fungal, anti-bacterial and anti-viral properties were also discovered from the secondary metabolites of S. lamellicola and S. obclavatum [31,54]. The entomopathogenity of S. lanosoniveum was demonstrated against silkworms, and it was evident that virulence of the isolate was strong as that of B. bassiana [38]. The present study strain, S. longisoniveum, exhibited $>70-80 \%$ mortality rates against RSW nymphs and pupae, while $>90 \%$ mortality recorded for egg stage at $1 \times 10^{7}$ and $1 \times 10^{8}$ conidia/mL under laboratory bioassays on seven DAT. It was noticed that early instars are highly susceptible to this fungal strain than the late instars. Present study results are corroborating the earlier report of Nagasi et al. [55], where, $B$. bassiana was found most virulent against the first instar of silver leaf whitefly, Bemisia argentifolii (Bellows \& Perring). Entomopathogenic fungi used as an effective biological control against in other whitefly species like, B. argentifolii and Trialeurodes vaporariorum (Westwood) [55-57]. Eyal et al. [58] reported that B. bassiana caused 52-98\% mortality in Bemisia tabaci (Gennadius) at concentrations of $1-4 \times 10^{6}$ conidia $/ \mathrm{mL}$. The present study observed increased mortality of different developmental stages of RSW with an increase in the conidial concentration and time of exposure. Likewise, Boopathi et al. [59] also observed that the application of I. fumosorosea was highly pathogenic to A. dispersus on cassava and exhibited differences in efficacy between 3 and 15 days after treatment. In the present study, the $\mathrm{LC}_{50}$ values and $\mathrm{LT}_{50}$ values of $S$. lanosoniveum against eggs, first instar, second to third instar, and pupae of RSW were $4.72 \times 10^{4}, 4.94 \times 10^{4}, 5.11 \times 10^{5}, 5.92 \times 10^{5}$ conidia $/ \mathrm{mL}$ and $4.27,4.86,4.56,5.89$ days, respectively. Similarly to present results, the $\mathrm{LC}_{50}$ values of I. fumosorosea for eggs, first-second, third and fourth instar nymphs of RSW were estimated to be $2.6 \times 10^{4}, 2.3 \times 10^{4}, 3.5 \times 10^{5}$ and $9.5 \times 10^{5}$ spores $/ \mathrm{mL}$ respectively and the $\mathrm{LT}_{50}$ values were4.19, 3.44, 5.62 and 5.69 , respectively for corresponding life stages for the concentration of $1 \times 10^{8}$ conidia/ $\mathrm{mL}$ tested [60]. Therefore, in terms of the pathogenicity bioassays, the $\mathrm{LC}_{50}$ and $\mathrm{LT}_{50}$ values of $S$. lanosoniveum exhibited significant biocontrol potential in the management of RSW under laboratory conditions. The results are comparable to the effects produced by the widely studied entomopathogenic fungi like I. fumosorosea [60]. However, S. longisoniveum at $1 \times 10^{8}$ conidia/mL tested under field conditions caused $57.8 \%$ and $56.3 \%$ mortality in the egg and nymphal population of RSW on 14 DAT, which was less than that of laboratory efficacy. The reason for this reduction in efficacy in the field condition might be due to the involvement of abiotic factors, as field conditions are heterogenetic in nature compared to the homogenic environment of the laboratory. Earlier 
reports also suggested that environmental factors not only affect survival and virulence of entomopathogenic fungi, but also influence their host-pathogen interaction [61]. Temperature and relative humidity are the two most important environmental factors which greatly influence the fungal germination, infection, sporulation, survival and virulence of the entomopathogenic fungi [62-64]. In addition, the process of fungal infection is also governed by the microclimate of the insect cuticle [65]. However, the sensitivity of the isolate or specific strain varies with environmental factors [62] and the success of any entomopathogenic fungi is determined by its adaptability to the local or prevailing environmental conditions [66]. Therefore, it is imperative to ascertain the effect of temperature and $\mathrm{RH}$ on any new isolate before considering it for biocontrol of insect pests. The fungal isolate reported herein performed fairly well in reducing the whitefly population in the open field conditions where the prevailing temperature and relative humidity conditions could have played a crucial role in affecting its efficacy. To conclude, this is the first report of natural occurrence of S. lanosoniveum on RSW. This study identified a highly pathogenic fungal isolate, S. lanosoniveum, based on its morphology, molecular and phylogeny and demonstrated its pathogenicity against RSW under in vitro and field conditions. Hence, this study forms a foundation for the large scale development of a biocontrol agent to suppress the spread of RSW. However, further studies on its compatibility with natural enemies for field applications are required. Efforts are also in progress to develop formulations with high virulent stability to sustain its field efficacy.

Author Contributions: Conceptualization, methodology, formal analysis, writing-original draft preparation, writing - review and editing, M.S., G.G.-P.-P., S.S.-N. and H.V.P. and supervision, project administration, investigation, M.S., H.V.P., M.R. and V.H. All authors have read and agreed to the published version of the manuscript.

Funding: This research received no external funding.

Institutional Review Board Statement: Not applicable.

Informed Consent Statement: Not applicable.

Data Availability Statement: The data presented in this study are available on request from the corresponding author.

Conflicts of Interest: The authors declare no conflict of interest.

\section{References}

1. Sundararaj, R.; Selvaraj, K. Invasion of rugose spiralling whitefly, Aleurodicus rugioperculatus (Hemiptera: Aleyrodidae): A potential threat to coconut in India. Phytoparasitica 2017, 45, 71-74. [CrossRef]

2. Martin, J.H. The whiteflies of Belize (Hemiptera: Aleyrodidae) Part 1-Introduction and account of the subfamily Aleurodicinae Quaintance and Baker. Zootaxa 2004, 681,1-119. [CrossRef]

3. Francis, A.W.; Stocks, I.C.; Smith, T.R.; Boughton, A.J.; Mannion, C.M.; Osborne, L.S. Host plants and natural enemies of rugose spiraling whitefly (Hemiptera: Aleyrodidae) in Florida. Fla. Entomol. 2016, 99, 150-153. [CrossRef]

4. Kumar, V.; Mckenzie, C.L.; Mannion, C.; Stocks, I.; Smith, T.; Osborne, L.S. Rugose spiraling whitefly, Aleurodicus rugioperculatus Martin (Hemiptera: Aleyrodidae). EENY578. University of Florida, IFAS Extension. Available online: https://entnemdept.ufl. edu/creatures/orn/Aleurodicus_rugioperculatus.htm (accessed on 5 January 2018).

5. Stocks, I.C.; Hodges, G. The Rugose Spiralling Whitefly, Aleurodicus rugioperculatus Martin, a New Exotic Whitefly in South Florida (Hemiptera: Aleyrodidae); DACS-P-01745; Florida Department of Agriculture and Consumer Services, Division of Plant Industry: Tallahassee, FL, USA, 2012; pp. 1-6.

6. Shanas, S.; Job, J.; Joseph, T.; Anjukrishnan, G. First report of invasive rugoase spiraling whitfely Aleurodicus rugioperculatus Martin (Hemiptera: Aleyrodidae) from the old world. Entomon 2016, 41, 365-368.

7. Selvaraj, K.; Sundararaj, R.; Venkatesan, T.; Ballal, C.R.; Jalali, S.K.; Gupta, A.; Mrudula, H.K. Potential natural enemies of the invasive rugose spiraling whitefly, Aleurodicus rugioperculatus Martin in India. J. Biol. Control 2016, 30, 236-239. [CrossRef]

8. Selvaraj, K.; Gupta, A.; Venkatesan, T.; Jalali, S.K.; Ballal, C.R.; Sundararaj, R. First record of invasive rugose spiraling whitefly Aleurodicus rugioperculatus Martin (Hemiptera: Aleyrodidae) along with parasitoids in Karnataka. J. Biol. Control 2017, 31, 74-78. [CrossRef]

9. Kepler, R.M.; Luangsa-Ard, J.J.; Hywel-Jones, N.L. A phylogenetically-based nomenclature for Cordycipitaceae (Hypocreales). IMA Fungus 2017, 8, 335-353. [CrossRef] 
10. Mascarin, G.M.; Kobori, N.N.; Quintela, E.D.; Delalibera, I. The virulence of entomopathogenic fungi against Bemisia tabaci biotype B (Hemiptera: Aleyrodidae) and their conidial production using solid substrate fermentation. Biol. Control 2013, 66, 209-218. [CrossRef]

11. Li, S.J.; Xue, X.; Ahmed, M.Z.; Ren, S.X.; Du, Y.Z.; Wu, J.H. Host plants and natural enemies of Bemisia tabaci (Hemiptera: Aleyrodidae) in China. Insect Sci. 2011, 18, 101-120. [CrossRef]

12. Faria, M.; Wraight, S.P. Biological control of Bemisia tabaci with fungi. Crop Prot. 2001, 20, 767-778. [CrossRef]

13. Gao, T.; Wang, Z.; Huang, Y.; Keyhani, N.O.; Huang, Z. Lack of resistance development in Bemisia tabaci to Isaria fumosorosea after multiple generations of selection. Sci. Rep. 2017, 7, 42727. [CrossRef] [PubMed]

14. Selvaraj, K.; Venkatesan, T.; Sumalatha, B.V.; Kiran, C.M. Invasive rugose spiralling whitefly Aleurodicus rugioperculatus Martin, a serious pest of oil palm Elaeis guinnensis in India. J. Oil Palm Res. 2019, 31, 651-656.

15. Humber, R.A. Identification of entomopathogenic fungi. In Manual of Techniques in Invertebrate Pathology; Lacey, L.A., Ed.; Academic Press: London, UK, 2012; pp. 151-187.

16. Zare, R.; Gams, W. A revision of Verticillium section Prostrata. IV. The genera Lecanicillium and Simplicillium gen. nov. Nova Hedwig. 2001, 73, 1-50. [CrossRef]

17. White, T.J.; Bruns, T.; Lee, S.; Taylor, J. Amplification and direct sequencing of fungal ribosomal RNA genes for phylogenetics. In PCR Protocols: A Guide to Methods and Applications; Innis, M.A., Gelfand, D.H., Sninsky, J.J., White, T.J., Eds.; Academic Press: San Diego, CA, USA, 1990; pp. 315-322.

18. Wei, D.-P.; Wanasinghe, D.N.; Hyde, K.D.; Mortimer, P.E.; Xu, J.-C.; Xiao, Y.-P.; Bhunjun, C.S.; Toanun, C. The genus Simplicillium. MycoKeys 2019, 60, 69-92. [CrossRef]

19. Kumar, S.; Stecher, G.; Li, M.; Knyaz, C.; Tamura, K. MEGA X: Molecular evolutionary genetics analysis across computing platforms. Mol. Biol. Evol. 2018, 35, 1547-1549. [CrossRef]

20. Abbott, W.S. A method for computing the effectiveness of an insecticide. J. Econ. Entomol. 1925, 18, 265-267. [CrossRef]

21. Finney, D.J. Probit Analysis; Cambridge University Press: Cambridge, UK, 1971; ISBN 052108041X.

22. Ritz, C.; Baty, F.; Streibig, J.C.; Gerhard, D. Dose-Response Analysis Using R. PLoS ONE 2015, 10, e0146021. [CrossRef] [PubMed]

23. Robertson, J.L.; Savin, N.E.; Russell, R.M.; Preisler, H.K. Bioassays with Arthropods; CRC Press: Boca Raton, FL, USA, 2007; ISBN 9780849323317.

24. Pandi, P.G.G.; Chander, S.; Pal, M.; Soumia, P.S. Impact of elevated $\mathrm{CO}_{2}$ on Oryza sativa phenology and brown planthopper, Nilaparvata lugens (Hemiptera: Delphacidae) population. Curr. Sci. 2018, 114, 1767-1777. [CrossRef]

25. Vega, F.E.; Goettel, M.S.; Blackwell, M.; Chandler, D.; Jackson, M.A.; Keller, S.; Koike, M.; Maniania, N.K.; Monzón, A.; Ownley, B.H. Fungal entomopathogens: New insights on their ecology. Fungal Ecol. 2009, 2, 149-159. [CrossRef]

26. Zimmermann, G. Review on safety of the entomopathogenic fungus Metarhizium anisopliae. Biocontrol Sci. Technol. 2007, 17, 879-920. [CrossRef]

27. Lacey, L.A.; Frutos, R.; Kaya, H.K.; Vail, P. Insect pathogens as biological control agents: Do they have a future? Biol. Control 2001, 21, 230-248. [CrossRef]

28. Butt, T.M.; Jackson, C.; Magan, N. (Eds.) Introduction: Fungal biological control agents: Progress, problems and potential. In Fungi as Biological Control Agents: Progress, Problems and Potential; CABI Publishing: Wallingford, UK, 2001; pp. 1-8.

29. Sun, J.Z.; Liu, X.Z.; McKenzie, E.H.; Jeewon, R.; Liu, K.J.; Zhang, X.L.; Zhao, Q.; Hyde, K.D. Fungicolous fungi: Terminology, diversity, distribution, evolution, and species checklist. Fungal Divers. 2019, 95, 337-430. [CrossRef]

30. Liang, X.; Zhang, X.Y.; Nong, X.H.; Wang, J.; Huang, Z.H.; Qi, S.H. Eight linear peptides from the deep-sea-derived fungus Simplicillium obclavatum EIODSF 020. Tetrahedron 2016, 72, 3092-3097. [CrossRef]

31. Dang, L.Q.; Shin, T.S.; Park, M.S.; Choi, Y.H.; Choi, G.J.; Jang, K.S.; Kim, I.S.; Kim, J.C. Antimicrobial Activities of Novel Mannosyl Lipids Isolated from the Biocontrol Fungus Simplicillium lamellicola BCP against Phytopathogenic Bacteria. J. Agric. Food Chem. 2014, 62, 3363-3370. [CrossRef]

32. Liu, F.; Cai, L. Morphological and molecular characterization of a novel species of Simplicillium from China. Cryptogam. Mycol. 2012, 33, 137-144. [CrossRef]

33. Chen, R.; Huang, C.; Li, J.; Tsay, J. Evaluation of characteristics of Simplicillium lanosoniveum on pathogenicity to aphids and in vitro antifungal potency against plant pathogenic fungi. Int. J. Environ. Agric. Res. 2017, 3. Available online: https: / /ijoear.com/Paper-January-2017/IJOEAR-JAN-2017-7.pdf (accessed on 5 January 2018).

34. Chen, W.H.; Liu, C.; Han, Y.F.; Liang, J.D.; Tian, W.Y.; Liang, Z.Q. Three novel insect-associated species of Simplicillium (Cordycipitaceae; Hypocreales) from Southwest China. MycoKeys 2019, 58, 83. [CrossRef]

35. Skaptsov, M.; Smirnov, S.; Kutsev, M.; Uvarova, O.; Sinitsyna, T.; Shmakov, A.; Matsyura, A. Pathogenicity of Simplicillium lanosoniveum to Coccus hesperidum. Ukr. J. Ecol. 2017, 7, 689-691. [CrossRef]

36. Wang, N.; Xie, Y.; Fan, J. Pathogenicity of Simplicillium lanosoniveum TYL001 isolated from Pseudaulacaspis pentagona. Mycosystema 2016, 35, 559-568.

37. Colmenarez, Y.; Moore, D.; Polar, P.; Vasquez, C. Population trends of the red palm mite, Raoiella indica hirst (Acari: Tenuipalpidae) and associated entomopathogenic fungi in Trinidad, Antigua, ST Kitts and Nevis and Dominica. Acarologia 2014, 54, 433-442. [CrossRef]

38. Lim, S.Y.; Lee, S.; Kong, H.G.; Lee, J. Entomopathogenicity of Simplicillium lanosoniveum isolated in Korea. Mycobiology 2014, 42, 317-321. [CrossRef] 
39. Zhao, D.; Liu, B.; Li, L.Y.; Zhu, X.F.; Wang, Y.Y.; Wang, J.Q.; Duan, Y.X.; Chen, L.J. Simplicillium chinense: A biological control agent against plant parasitic nematodes. Biocontrol Sci. Technol. 2013, 23, 980-986. [CrossRef]

40. Polar, P.; Kairo, M.T.K.; Moore, D.; Pegram, R.; John, S.; Peterkin, D. Assessment of fungal isolates for the development of a myco-acaricide for cattle tick control. Vector Borne Zoonotic Dis. 2005, 5, 276-284. [CrossRef]

41. Hyde, K.D.; Xu, J.; Rapior, S.; Jeewon, R.; Lumyong, S.; Niego, A.G.T.; Abeywickrama, P.D.; Aluthmuhandiram, J.V.; Brahamanage, R.S.; Brooks, S. The amazing potential of fungi: 50 ways we can exploit fungi industrially. Fungal Divers. 2019, 97, 1-136. [CrossRef]

42. Yan, B.F.; Fang, S.T.; Li, W.Z.; Liu, S.J.; Wang, J.H.; Xia, C.H. A new minor diketopiperazine from the sponge-derived fungus Simplicillium sp. YZ-11. Nat. Prod. Res. 2015, 29, 2013-2017. [CrossRef] [PubMed]

43. Takata, K.; Iwatsuki, M.; Yamamoto, T.; Shirahata, T.; Nonaka, K.; Masuma, R.; Hayakawa, Y.; Hanaki, H.; Kobayashi, Y.; Petersson, G.A.; et al. Aogacillins A and B produced by Simplicillium sp. FKI-5985: New circumventors of arbekacin resistance in MRSA. Org. Lett. 2013, 15, 4678-4681. [CrossRef]

44. Chen, R.S.; Huang, C.C.; Li, J.C.; Tsay, G.J. First report of Simplicillium lanosoniveum causing brown spot on Salvinia auriculata and S. molesta in Taiwan. Plant Dis. 2008, 92, 1589. [CrossRef]

45. Ward, N.; Schneider, R.W.; Aime, M.C. Colonization of soybean rust sori by Simplicillium lanosoniveum. Fungal Ecol. 2011, 4, 303-308. [CrossRef]

46. Gauthier, N.W.; Maruthachalam, K.; Subbarao, K.V.; Brown, M.; Xiao, Y.; Robertson, C.L.; Schneider, R.W. Mycoparasitism of Phakopsora pachyrhizi, the soybean rust pathogen, by Simplicillium lanosoniveum. Biol. Control 2014, 76, 87-94. [CrossRef]

47. Scopel, M.; de Santos, O.; Frasson, A.P.; Abraham, W.R.; Tasca, T.; Henriques, A.T.; Macedo, A.J. Anti-Trichomonas vaginalis activity of marine-associated fungi from the south Brazilian coast. Exp. Parasitol. 2013, 133, 211-216. [CrossRef]

48. Luyen, V.T. Identification of the entomopathogenic fungi sample DL0069 by combination of morphological and molecular phylogenetic analyses. Vietnam J. Sci. Technol. 2017, 55, 117-123. [CrossRef]

49. Shin, T.S.; Yu, N.H.; Lee, J.; Choi, G.J.; Kim, J.C.; Shin, C.S. Development of a biofungicide using a mycoparasitic fungus Simplicillium lamellicola BCP and its control efficacy against gray mold diseases of tomato and ginseng. Plant Pathol. J. 2017, 33, 337-344. [CrossRef]

50. Yu, Y.T.; He, S.H.; Zhao, Q.M. Isolation and identification of matrine-producing fungal endophytes from Sophora alopecuroides in Ningxia. Sci. Agric. Sin. 2013, 46, 2643-2654. [CrossRef]

51. Fukuda, T.; Sudoh, Y.; Tsuchiya, Y.; Okuda, T.; Igarashi, Y. Isolation and biosynthesis of preus sin B, a pyrrolidine alkaloid from Simplicillium lanosoniveum. J. Nat. Prod. 2014, 77, 813-817. [CrossRef] [PubMed]

52. Xing, X.Y.; Chen, J.Y.; Dong, Q.L.; Guan, R.J.; Yan, S.Y. Optimization and kinetics analyses of exopolysaccharide production by Simplicillium lanosoniveum. Sci. Technol. Food Ind. 2016, 37, 185-191. [CrossRef]

53. Dong, Q.L.; Dong, R.Z.; Xing, X.Y.; Li, Y.K. A new antibiotic produced by the cyanobacterium-symbiotic fungus Simplicillium lanosoniveum. Nat. Prod. Res. 2018, 32, 1348-1352. [CrossRef]

54. Liang, X.; Nong, X.H.; Huang, Z.H.; Qi, S.H. Antifungal and antiviral cyclic peptides from the deep-sea-derived fungus Simplicillium obclavatum EIODSF 020. J. Agric. Food Chem. 2017, 65, 5114-5121. [CrossRef]

55. Nagasi, A.; Paster, B.L.; Brownsbridge, M. Screening and bioassay of entomopathogenic fungi for the control of silver leaf whitefly, Bemisia argentifolia. Insect Sci. Appl. 1998, 18, 37-44.

56. Scorsetti, A.C.; Humber, R.A.; De Gregorio, C.; Lastra, C.C.L. New records of entomopathogenic fungi infecting Bemisia tabaci and Trialeurodes vaporariorum, pests of horticultural crops in Argentina. Biocontrol 2008, 53, 787-796. [CrossRef]

57. Wraight, S.P.; Carruthersb, R.I.; Bradley, C.A.; Jaronski, S.T.; Lacey, L.A.; Wood, P.; Galaini-Wraight, S. Pathogenicity of the entomopathogenic fungi Paecilomyces spp. and Beauveria bassiana against the silverleaf whitefly, Bemisia argentifolii. J. Invertebr. Pathol. 1998, 71, 217-226. [CrossRef]

58. Eyal, J.; Mabud, M.A.; Fischbein, K.L.; Walter, J.F.; Osborne, L.S.; Landa, Z. Assessment of Beauveria bassiana Nov. EO-1 strain, which produces a red pigment for microbial control. Appl. Biochem. Biotechnol. 1994, 44, 65-80. [CrossRef]

59. Boopathi, T.; Karuppuchamy, P.; Singh, B.S.; Kalyanasundaram, M.; Mohankumar, S.; Ravi, M. Microbial control of the invasive spiraling whitefly on cassava with entomopathogenic fungi. Braz. J. Microbiol. 2015, 46, 1077-1085. [CrossRef]

60. Sumalatha, B.V.; Selvaraj, K.; Poornesha, B.; Ramanujam, B. Pathogenicity of entomopathogenic fungus Isaria fumosorosea on rugose spiralling whitefly Aleurodicus rugioperculatus and its effect on parasitoid Encarsia guadeloupae. Biocontrol Sci. Technol. 2020, 30, 1150-1161. [CrossRef]

61. Kiewnick, S. Effect of temperature on growth, germination, germ-tube extension and survival of Paecilomyces lilacinus strain 251. Biocontrol Sci. Technol. 2006, 16, 535-546. [CrossRef]

62. Bugeme, D.M.; Maniania, N.K.; Knapp, M.; Boga, H.I. Effect of temperature on virulence of Beauveria bassiana and Metarhizium anisopliae isolates to Tetranychus evansi. Exp. Appl. Acarol. 2008, 46, 275-285. [CrossRef] [PubMed]

63. Yeo, Y.; Pell, J.K.; Alderson, P.G.; Clark, S.J.; Pye, B.J. Laboratory evaluation of temperature effects on the germination and growth of entomopathogenic fungi and on their pathogenicity to two aphid species. Pest Manag. Sci. 2003, 59, 156-165. [CrossRef] [PubMed]

64. Fargues, J.; Goettel, M.S.; Smith, N.; Ouedraogo, A.; Rougier, M. Effect of temperature on vegetative growth of Beauveria bassiana isolates from different origins. Mycologia 1997, 89, 383-392. [CrossRef] 
65. Devi, K.U.; Sridevi, V.; Mohan, C.M.; Padmavathi, J. Effect of high temperature and water stress on in vitro germination and growth in isolates of the entomopathogenic fungus Beauveria bassiana (Bals.) Vuillemin. J. Invertebr. Pathol. 2005, 88, 181-189. [CrossRef]

66. Senthil Kumar, C.M.; Jacob, T.K.; Devasahayam, S.; D'Silva, S.; Kumar, N.K.K. Isolation and characterization of a Lecanicillium psalliotae isolate infecting cardamom thrips (Sciothrips cardamomi) in India. BioControl 2015, 60, 363-373. [CrossRef] 